\title{
Website Management Training and ICT Literacy Evaluation of Kelurahan Ciwaringin Bogor Authorities
}

\author{
Halimah Tus Sadiah ${ }^{\mathrm{a}}$, Muhamad Saad Nurul Ishlah ${ }^{\mathrm{a}}$ \\ ${ }^{a}$ Manajemen Informatika, Universitas Pakuan, Bogor, 16143 Indonesia \\ Corresponding author e-mail address: sadiahht@unpak.ac.id
}

\begin{abstract}
The use and management of e-Government websites as a mean of public service among Kelurahan Ciwaringin Bogor (Ciwaringin Bogor Village) officials are still considered low. This has implications on the level of online public services in Ciwaringin Bogor Village which is less optimal. This research aims to provide website management training and to conduct an evaluation on information and communications technology (ICT) literacy prior to (plan) and after (reflect) the training of Ciwaringin Bogor Village authorities in order to optimize the usage of e-Government website for public service improvement purpose. The research method consists of three stages, namely: Planning, Website Management Training, and Reflecting. The training is conducted 10 times from February 2019 to April 2019. Based on evaluation of the planning and reflecting stages, the authorities are ready for ICT usage and management as there is a significant improvement in e-Government website management skill of the Ciwaringin Bogor Village authorities from $40 \%$ to $80 \%$.
\end{abstract}

Keywords: e-Government, Website Management Training, ICT Literacy, Village Authorities.

\section{Introduction}

Ciwaringin Village is one of the villages located in Bogor City. This village office is located at Jl. R.E. Martadhinata No. 40. Prior to the training, there are already several web-based applications being used in the office. A web-based application is an information page that can be accessed throughout the world using a web browser as long as it is connected to the internet network (Al-Fedaghi 2011, Herdianto 2014, Kumar 2015, Nabil et al 2011, Raveena 2018). At the Ciwaringin Village Office, they are various webbased applications, ranging from profile web, service management applications, certificate applications and other e-government applications to support reporting automation or information service needs. Egovernment is defined as a way for governments to use the most innovative information and communication technologies, particularly web-based Internet applications, to provide citizens and 
businesses with more convenient access to government information and services, to improve the quality of the services and to provide greater opportunities to participate in democratic institutions and processes (Fang 2002, Alshehri \& Drew 2010). Unfortunately, those e-Government websites web-based applications are only managed by one Village officer, so that if the officer is not available, because of sick, for example, the applications and services management is hampered. Thus, whenever some other officers want to upload or update data, he/she would have to share the data via email. This results in the accumulation of data in the village officials' e-mails and the process of uploading data would take time and a long process. Therefore, it is necessary to conduct a website management training for village officials so that other village officials are able to manage public service-related tasks. In addition, the existence of this website management training is expected to improve the information and communications technology (ICT) capabilities of the Ciwaringin Bogor Village authorities in general.

As for website management training, an ICT Literacy evaluation is conducted. ICT is any system designed to gather, process and distribute information (Haneefa and Shukkoor 2010) that is an important tool to help people communicate effectively (Samah et al 2010, Ranade et al 2015, Atieno 2014). Information Technology (IT) is regarded as an important tool in the constant efforts of public administrations to increase efficiency (Al-Kaseasbeh 2019, Mohammed et al 2013, Tosida 2012). According to Educational Testing Service (ETS) (2006), ICT literacy is the ability of someone to use digital technology, communication tools, or networks to define, access (collect and/or retrieve information), manage (apply an existing organization), integrate (Interpreting and representing information), evaluate (make judgments about the quality), and create (Generating information by adapting, applying, designing, inventing, or authoring information) (ETS 2006, Pérez and Murray 2010). ICT literacy evaluation, which is an evaluation to measure the ability of ICT using a questionnaire (Anugrah 2017, Sadiah 2015, Sianturi 2014). Measurement of ICT literacy in the need for system development was previously carried out by Sadiah (2015), namely measuring ICT Literacy for Soybean Farmer. Then research by Anugrah (2017), measuring ICT literacy instructor and Evaluation of Farmer Literacy ICT by Nurhardyani et al (2018). This paper will measure ICT Literacy of village officials in order to measure the ability of village officials to recognize and manage websites. This study aims to conduct training on website management and measurement of ICT literacy in Ciwaringin village authorities. This research is expected to be able to improve the ICT capability of village officials so that all village officials in Ciwaringin village can manage website-based applications (Tosida et al., 2019.a; 2019.b).

\section{Materials and Method}

\subsection{Venue and Time of Training}

Web usage training is carried out in Ciwaringin District, Bogor. The training was held from February to April 2019.

\subsection{Tools in used}

There are various tools used for website management training, but the main things are personal computers and laptops with core i3 specifications with intel graphics. The tools used in web management training and assistance are web browsers and village service applications. The material used is data from the village and Curiculum vitae data from the Ciwaringin Village officers.

\subsection{Methods}

The implementation method has three parts, namely Plan, Website Management Training, Reflect (Khikmiyah et al 2017). 


\subsubsection{Plan}

At the plan stage an ICT Literacy evaluation was carried out using a questionnaire. The questionnaire consisted of the characteristics of the village staff, and the measurement of ICT literacy based on the ICT element according to ETS (2006). There are 6 variables used in measuring ICT literacy, namely: define, access, create, evaluate, manage and integrate (Anugrah 2017, Sadiah 2015). The data were analysed descriptively in the form of presentation (\%) of each element of ICT literacy. Questions with the answer 'Yes' are given a weighting value of 1 and the answer 'No' are given a zero-weight value (Sianturi 2014, Sadiah 2015, Anugrah 2017 \& Nurhardyani et al 2018).

\subsubsection{Website Training and Management Assistance}

Assistance activities were carried out 10 times using demonstration and intensive training methods. Demonstration methods are provided to explain step by step on how to use and manage Village Information System (Indrihapsari, et al 2012). The demonstration method was carried out on the first and second mentoring. As for the intensive training, the village officials are able to master the use and management of the website. The training was conducted in the third to tenth mentoring activities. The accompanying materials are shown in Table 1.

Table 1. Website Training and Management Assistance Materials

\begin{tabular}{|c|c|c|}
\hline Activity & Materials & Methods \\
\hline Assistance 1 & $\begin{array}{l}\text { Introduction to email, Google Drive, and } \\
\text { website application front-end }\end{array}$ & Demonstration \\
\hline Assistance 2 & $\begin{array}{l}\text { Introduction to website application } \\
\text { back-end }\end{array}$ & Demonstration \\
\hline Assistance 3 & $\begin{array}{l}\text { New Account Creation in the } \\
\text { application, CRUD (Create Read } \\
\text { Update Delete) of Google Drive, } \\
\text { activities data, and uploading activities } \\
\text { photos }\end{array}$ & Training Exercise \\
\hline Assistance 4 & $\begin{array}{l}\text { How to edit organisation structure and } \\
\text { profile in the application. }\end{array}$ & Training Exercise \\
\hline Assistance 5 & $\begin{array}{l}\text { CRUD on automatic certificate creation } \\
\text { using the application }\end{array}$ & Training Exercise \\
\hline Assistance 6 & $\begin{array}{l}\text { CRUD on making reports in the form of } \\
\text { service data recap }\end{array}$ & Training Exercise \\
\hline Assistance 7 & CRUD on population data recap & Training Exercise \\
\hline Assistance 8 & CRUD on featured products data & Training Exercise \\
\hline Assistance 9 & CRUD on events creation & Training Exercise \\
\hline Assistance 10 & $\begin{array}{l}\text { Training on how to respond to incoming } \\
\text { service notification, data searching, and } \\
\text { data filtering }\end{array}$ & Training Exercise \\
\hline
\end{tabular}




\subsubsection{Reflect}

Reflect is an evaluation of ICT Literacy after website management training is finished conducted. This evaluation is conducted with the aim to measure the increase in the ability of authorities' ICT Literacy after receiving training. This evaluation is carried out using the same questionnaire in the evaluation phase of the plan.

\section{Results and Discussion}

Training activities and assistance for village officials are conducted to train the village officials in managing email, google drives and the web as e-Government. Training activities can be seen in Figure 1. Mentoring and training is more specifically on the back-end page. One of the activities in the training is that village officials are asked to fill in a new admin according to their respective username and password. The results of adding admin data are shown in Figure 2. The next is the activity data update in the Village office and the use of other menus in accordance with the material for each meeting.

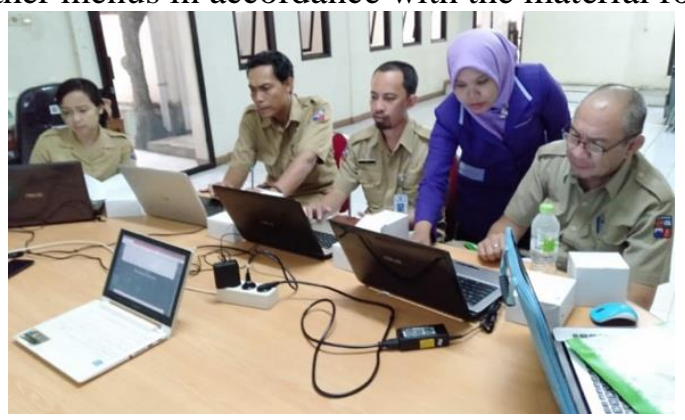

Figure 1. Assistance Training of Ciwaringin Website

\begin{tabular}{|c|c|c|}
\hline \multicolumn{3}{|c|}{ ADMIN } \\
\hline \multicolumn{3}{|c|}{ + Tambah Admin } \\
\hline & & \\
\hline No & UserName & Password \\
\hline 4 & admin & 12345 \\
\hline 5 & admin & martadinat \\
\hline
\end{tabular}

Figure 2: The result of admin data addition by Village staffs

The implementation of the plan and reflect phases result in the ICT literacy evaluation of village officials. As for the characteristics of respondents in the measurement of ICT literacy of village officials consists of gender, age, education, experience of being a village officer and the number of experiences in participating in ICT training. Table 2 shows the characteristics of respondents in Ciwaringin village officials. 
Table 2. Characteristics of Respondents

\begin{tabular}{|c|c|}
\hline \multicolumn{2}{|l|}{ Gender } \\
\hline Men & $80 \%$ \\
\hline Women & $20 \%$ \\
\hline \multicolumn{2}{|l|}{ Age (Year) } \\
\hline $30-40$ & $60 \%$ \\
\hline $40-50$ & $20 \%$ \\
\hline $50-60$ & $20 \%$ \\
\hline \multicolumn{2}{|l|}{ Education Level } \\
\hline SMA/SMK Sederajat (High School) & $20 \%$ \\
\hline S1 (Undergraduate) & $40 \%$ \\
\hline S2 (Postgraduate) & $40 \%$ \\
\hline \multicolumn{2}{|l|}{ Working Period (Year) } \\
\hline $1-5$ & $40 \%$ \\
\hline $5-10$ & $40 \%$ \\
\hline $10-20$ & $20 \%$ \\
\hline \multicolumn{2}{|l|}{ Training Experience in ICT } \\
\hline $1-5$ times & $60 \%$ \\
\hline 5-10 times & $20 \%$ \\
\hline 10-20 times & $20 \%$ \\
\hline
\end{tabular}

Based on the results of the evaluation of respondents' characteristics (Table 2), $60 \%$ of respondents are in the productive age so that the village officials are still able to receive knowledge in the management of web-based applications. In addition, $80 \%$ of Ciwaringin Village officials have quite high education, two staffs of S1 (undergraduate) and two staffs of S2 (postgraduate) so that they are able to adopt innovation. The ICT Literacy Evaluation Data of Village officials in the plan and reflect stages are shown in Table 3.

Table 3. ICT literacy evaluation of Village Officials

\begin{tabular}{|c|c|c|c|c|c|}
\hline \multirow{2}{*}{$\begin{array}{c}\text { ICT } \\
\text { Literacy } \\
\text { Element }\end{array}$} & \multirow{2}{*}{ Question } & \multicolumn{2}{|c|}{$\begin{array}{c}\text { Percentage of Respondents } \\
\text { answered "Yes" }\end{array}$} & \multicolumn{2}{|c|}{$\begin{array}{l}\text { Average percentage } \\
\text { of Respondents } \\
\text { answered "Yes" }\end{array}$} \\
\hline & & $\begin{array}{l}\text { Prior to } \\
\text { Training } \\
\text { (plan) }\end{array}$ & $\begin{array}{l}\text { After Training } \\
\quad \text { (Reflect) }\end{array}$ & $\begin{array}{l}\text { Prior to } \\
\text { Training } \\
\text { (plan) }\end{array}$ & $\begin{array}{c}\text { After } \\
\text { Training } \\
\text { (Reflect) }\end{array}$ \\
\hline \multirow{4}{*}{ Access } & $\begin{array}{l}\text { User is able to open web } \\
\text { browser }\end{array}$ & $100 \%$ & $100 \%$ & \multirow{4}{*}{$64 \%$} & \multirow{4}{*}{$84 \%$} \\
\hline & User is able to open WhatsApp & $100 \%$ & $100 \%$ & & \\
\hline & $\begin{array}{l}\text { User is able to open web-based } \\
\text { application of Village e- } \\
\text { Government }\end{array}$ & $60 \%$ & $100 \%$ & & \\
\hline & User is able to access Google & $40 \%$ & $60 \%$ & & \\
\hline
\end{tabular}




\begin{tabular}{|c|c|c|c|c|c|}
\hline & Translate & & & & \\
\hline & $\begin{array}{l}\text { User is able to open Google } \\
\text { Drive }\end{array}$ & $20 \%$ & $60 \%$ & & \\
\hline \multirow{5}{*}{ Manage } & $\begin{array}{l}\text { User has ever forwarded } \\
\text { email message }\end{array}$ & $80 \%$ & $80 \%$ & \multirow{5}{*}{$42 \%$} & \multirow{5}{*}{$80 \%$} \\
\hline & $\begin{array}{l}\text { User has ever updated data on } \\
\text { web application }\end{array}$ & $20 \%$ & $80 \%$ & & \\
\hline & $\begin{array}{l}\text { User has ever edited profile on } \\
\text { Facebook }\end{array}$ & $80 \%$ & $80 \%$ & & \\
\hline & $\begin{array}{l}\text { User has ever set "message has } \\
\text { been read report" }(W) \text { in } \\
\text { WhatsApp }\end{array}$ & $40 \%$ & $80 \%$ & & \\
\hline & $\begin{array}{l}\text { User has ever saved data in } \\
\text { Google Drive }\end{array}$ & $20 \%$ & $80 \%$ & & \\
\hline \multirow{5}{*}{ Evaluate } & $\begin{array}{l}\text { User is able to evaluate image } \\
\text { clarity }\end{array}$ & $80 \%$ & $80 \%$ & \multirow{5}{*}{$64 \%$} & \multirow{5}{*}{$80 \%$} \\
\hline & $\begin{array}{l}\text { User is able to evaluate easy to } \\
\text { read font type }\end{array}$ & $60 \%$ & $80 \%$ & & \\
\hline & $\begin{array}{l}\text { User is able to evaluate } \\
\text { Google Maps for location } \\
\text { finder application }\end{array}$ & $40 \%$ & $80 \%$ & & \\
\hline & $\begin{array}{l}\text { User is able to evaluate } \\
\text { WhatsApp call feature quality }\end{array}$ & $60 \%$ & $80 \%$ & & \\
\hline & $\begin{array}{l}\text { User is able to evaluate the } \\
\text { color contrast in background } \\
\text { and writing }\end{array}$ & $80 \%$ & $80 \%$ & & \\
\hline \multirow{5}{*}{ Integrate } & $\begin{array}{l}\text { User is able to attach file in } \\
\text { email }\end{array}$ & $60 \%$ & $80 \%$ & \multirow{5}{*}{$32 \%$} & \multirow{5}{*}{$72 \%$} \\
\hline & $\begin{array}{l}\text { User is able to upload image in } \\
\text { web-based application }\end{array}$ & $20 \%$ & $80 \%$ & & \\
\hline & $\begin{array}{l}\text { User is able to use location } \\
\text { sharing in WhatsApp }\end{array}$ & $40 \%$ & $80 \%$ & & \\
\hline & $\begin{array}{l}\text { User has ever done the } \\
\text { WhatsApp web synchronization }\end{array}$ & $20 \%$ & $60 \%$ & & \\
\hline & $\begin{array}{l}\text { User has ever done Google } \\
\text { Drive synchronization to } \\
\text { personal computer }\end{array}$ & $20 \%$ & $60 \%$ & & \\
\hline \multirow{5}{*}{ Create } & $\begin{array}{l}\text { User is able to create email } \\
\text { account in Internet }\end{array}$ & $80 \%$ & $100 \%$ & \multirow{5}{*}{$48 \%$} & \multirow{5}{*}{$96 \%$} \\
\hline & $\begin{array}{l}\text { User is able to add data in web } \\
\text { application }\end{array}$ & $20 \%$ & $100 \%$ & & \\
\hline & $\begin{array}{l}\text { User is able to create an email } \\
\text { message }\end{array}$ & $60 \%$ & $100 \%$ & & \\
\hline & $\begin{array}{l}\text { User is able to create status } \\
\text { in WhatsApp }\end{array}$ & $60 \%$ & $100 \%$ & & \\
\hline & $\begin{array}{l}\text { User is able to create a folder in } \\
\text { Google Drive }\end{array}$ & $20 \%$ & $80 \%$ & & \\
\hline
\end{tabular}




\begin{tabular}{|c|c|c|c|c|c|}
\hline \multirow{5}{*}{ Define } & User recognizes browser icon & $60 \%$ & $100 \%$ & \multirow{5}{*}{$52 \%$} & \multirow{5}{*}{$100 \%$} \\
\hline & $\begin{array}{l}\text { User recognized notification } \\
\text { icon in web-based application }\end{array}$ & $60 \%$ & $100 \%$ & & \\
\hline & User recognizes email icon & $80 \%$ & $100 \%$ & & \\
\hline & $\begin{array}{l}\text { User recognizes Google } \\
\text { Translate icon }\end{array}$ & $40 \%$ & $100 \%$ & & \\
\hline & $\begin{array}{l}\text { User recognizes Google } \\
\text { Drive icon }\end{array}$ & $20 \%$ & $100 \%$ & & \\
\hline
\end{tabular}

Evaluation of training activities and assistance in using Email, Google Drive and website management is carried out through the ICT Literacy Web questionnaire. Respondents must fill in the questionnaire by binary method (yes or no). Based on the results of the web evaluation at the plan and reflect stages (Table 2), the results of the training and mentoring that have been carried out have a positive impact in the form of improving the ICT literacy capacity of the Village officials. This can be seen in Figure 3, that the ICT literacy measurement results of village officials have increased from 40\% to $80 \%$. This shows that the ability to manage is already high, namely $80 \%$, indicating that the Village officials are ready in implementing web management technology.

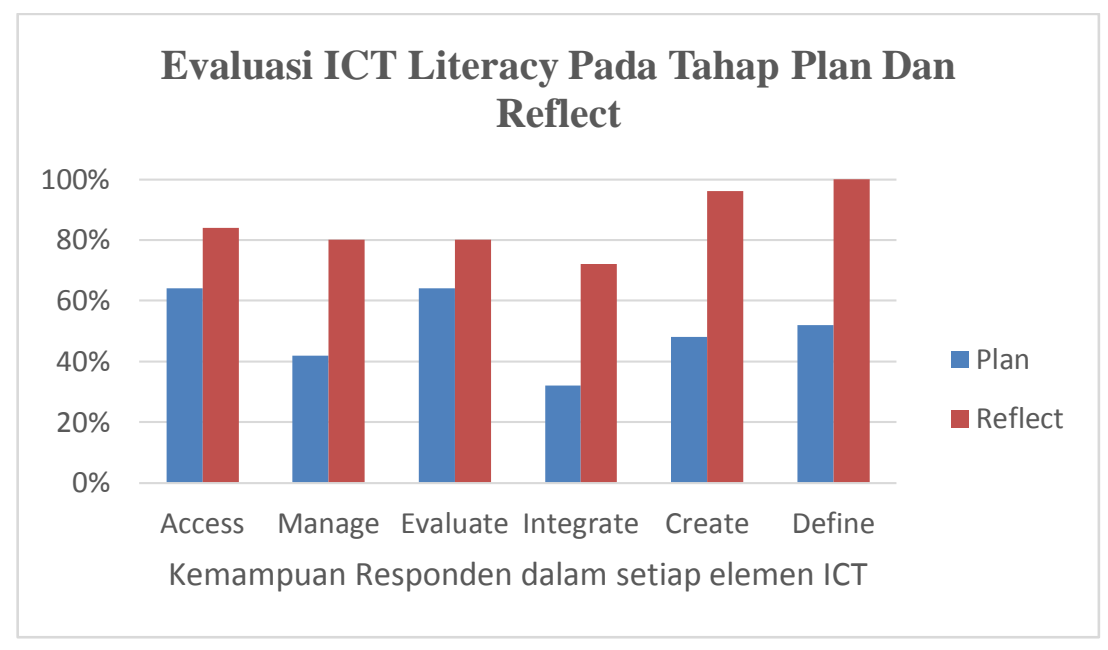

Figure 1: Evaluation result of ICT Literacy of Village authorities on Plan and Reflect stages

\section{Conclusion}

Village officials have difficulty in managing applications, especially website-based applications. Based on this, it is necessary to conduct a website management training for village officials and evaluation of ICT literacy before training (plan) and after training (reflect) to know the positive impact of the training. The training was conducted 10 times from February 2019 to April 2019. Based on the data from the evaluation of the web at the stage of the plan and reflect the results of the training and mentoring that had been carried out had a positive impact in the form of increasing the ICT literacy capacity of the village apparatus. Village officials have increased the ability to manage from $40 \%$ to $80 \%$. This shows that the ability to manage is already high, namely $80 \%$, indicating that the Village authorities are ready to implement web management technology. 


\section{Acknowledgments}

This research is part of the implementation of the internal community partnership program (PKM) of Universitas Pakuan. The authors would like to thank LPPM Universitas Pakuan for funding this activity.

\section{References}

Alshehri, M, and Drew S. (2010). E-Government Fundamentals. IADIS International Conference ICT, Society and Human Beings : 35-42.

Alshehri, M, Drew, and Steve. (2010). Implementation of e-Government: Advantages and Challenges . IIASK EALT2010 Conference Proceedings: 79-86.

Al-Fedaghi S. 2011. Developing Web Applications. International Journal of Software Engineering and Its Applications. 5 (2), 57-68.

Al-Kaseasbeh H M, Harada Y, and Saraih U.N.B. (2019). E-Government Services Assessment from the Perspective of Citizens Interaction and Satisfaction in Jordan: Pilot Study. International Journal of Research \& Review. 6 (12), 50-56.

Anugrah W P. (2017). ICT Literacy Measurement of Agriculture Extension and Usability Testing for Soybean Knowledge Management System. [Thesis]. Bogor (ID): IPB University.

Atieno L V and Motur C A. (2014). Implementation of Digital Village Projects in Developing Countries - Case of Kenya. British Journal of Applied Science \& Technology. 4(5), 793-80.

[ETS] Educational Testing Service. (2006). Digital transformation a framework for ICT literacy. A Report of the International ICT literacy Panel. [Internet]. [diunduh $2014 \quad$ Mei 28]; http://www.ets.org/Media/Research/pdf/ ICTREPORT.pdf].

Fang Z. (2002). E-Government in Digital Era: Concept, Practice, and Development. International Journal of The Computer, The Internet and Management, Vol. 10(2), 1-22

Haneefa M.K, and Shukkoor C.K.A (2010). Information and Communication technology literacy among Library Professional in Calicut University, Kerala. DESIDOC Journal of Library \& Information Technology. 30 (5), 55-63.

Indrihapsari Y, Irmawati D, and Irfan R. (2012). Pelatihan dan Pendampingan Pengembangan web Pembelajaran Interaktif bagi guru SMK menuju sekolah berstandar internasional. Universitas Negeri Yogyakarta. Yogyakarta.

Herdianto D.E.(2014). Pembuatan Sistem Informasi Perpustakaan Berbasis Website Pada Sekolah Menegah Pertama Negeri 1 Donorojo Kabupaten Pacitan. IJNS - Indonesian Journal on Networking and Security, 3 (4), 57-64.

Khikmiyah F, Asmara CH, and Bakhtiar AM. (2017). IbM Guru: Pelatihan dan Pendampingan Pengembangan Buku Ajar Literasi Matematika dan Bahasa. .International. Journal of Community Service Learning, 1 (3), 109-117.

Kumar N, Dadhich, and Shastri A. 2015. Quality Models for Web-based Application: A Comparative Study. International Journal of Computer Applications (0975 - 8887). 125 (2), 25-32.

Mohammed, M., Ibrahim, H. B., and Shawkat, A. R., \& Hasson, A. R. (2013). Implementation of Data warehouse Architecture for Egovernment of Malaysian Public Universities to Increase Information sharing between them. In Proceedings of the International Conference on Rural ICT Development:1-8.

Nabil D, Mosad A, and Hefny.H.A .2011. Web-Based Applications quality factors: A survey and a proposed conceptual model. Egyptian Informatics Journal. 12 (3), 211-217.

Nurhadryani Y, Sadiah HT, Wirnas D, Ardiansyah F. 2018. Evaluation Of Soybean Farmer's Ict (Information And Communication Technology) Literacy,. 5(2),128-133.

Pérez J, and Murray M.C. (2010). Generativity: The New Frontier for Information and Communication Technology Literacy.Interdisciplinary Journal of Information, Knowledge \& Management. 5(1), 127-137. 
Ranade P, Londhe S, and Mishra A. (2015) .Smart Villages Through Information Technology - Need Of Emerging India. IPASJ International Journal of Information Technology (IIJIT). 3(7), 1-6.

Raveena K, Elavarasi K and Kaaviyapriya.2018. Survey on Web Application Development. Asian Journal of Applied Science and Technology (AJAST)(Open Access Quarterly International Journal). 2 (2), 143-147.

Sadiah HT. (2015). ICT Literacy Analysis of Soybean Farmers and Development of soybean KMS using Information Architecture Concept. [Thesis]. Bogor (ID): IPB University.

Samah B.A, Shaffril H.A.M, and D'Silva J.L (2010). Information Communication Technology, Village Development and Security Committee and Village Vision Movement: A Recipe for Rural Success in Malaysia. Asian Social Science, 6(4), 136-144.

Sianturi S. (2014). Design and Usability Testing to enhance Mobile Application User Interface. [Thesis]. Bogor (ID): IPB University.

Tosida E.T, Harsanai P, Hermawan, and Setyaningsih S. (2012). Classification Models of Information Technology Services Bussiness in Indonesia. Proceeding International Seminar on Science and Technology Innovations: 1-7.

Tosida, E.T., Ardiansyah, D., Walujo, A.D., and Sofyandi, A. (2019.a). System Design of Augmented Reality Technology to Strengthen Sustainable Imaging of Kujang Products Based on Local Culture. International Journal of Recent Technology and Engineering (IJRTE), ISSN : 2277-3878, Vol. 8, Issue 4, Nov 2019, pp 5940- 5949.

Tosida E.T., Hermawan, Andria, F., Wahyudin, I., and Djatna, T. (2019.b). Development Strategy for Telematics Small and Medium Industries in Indonesia. Jurnal Penelitian Pos dan Informatika, 2019, Vol 9 No. 1, 090104. 